\title{
Histological Study of Rete Testis and Ductuli efferentes of Rabbit (Oryctolagus cuniculus)
}

\author{
Rakhmiyati $^{1}$, Muhammad Jafar Luthfi ${ }^{2}$ \\ ${ }^{1}$ Postgraduate Program, Universitas Sebelas Maret \\ J1 Ir. Sutami 36 A, Surakarta, 57126, Tel. +62 271-646994, Fax. +62 271-646655, Indonesia \\ ${ }^{2}$ Biology Education Department, Faculty of Science and Technology, UIN Sunan Kalijaga \\ J1. Marsda Adisucipto No 1 Yogyakarta 55281, Indonesia. Tel. +62-274-540971, Fax. +62-274-519739 \\ 1Email: miarakhmiy@gmail.com
}

\begin{abstract}
The testes produce sperm cells through the spermatogenesis process that occurs in the complex system ducts starting form seminiferous tubules to vas deferens. Testis has a very complex part to support sperm cell production. Sperm cells that have been formed through the process of spermatogenesis will move towards the lumen in the seminiferous tubules. Then the sperm cells will pass through the rete testis tissue, then to ductuli efferentes to arrive at the epididymis for the process of maturing sperm. Anatomical studies on seminiferous tubular tissue and epididymal organs have often been carried out, but there is still very little observation data on rete testis and ductuli efferentes in rabbits. The method used in this study was the paraffin method with hematoxylin-eosin (HE) staining. The observations showed that the structure of the testicular rete channels had thin walls compared to the seminifous tubule channels. Ductuli efferens is a channel between of rete testis and epididymis.
\end{abstract}

Keywords: Ductuli efferentes, Rabbit (Oryctolagus cuniculus), Rete testis

\section{INTRODUCTION}

Testis is a part of the male genital organs in mammals, most of which is dominated by seminiferous tubular tissue (Caldeira et al., 2010). Anatomically, testis is covered with scrotal and irregular solid connective tissue. (Zamora, E. J. L et al., 2014). The outermost part of the testis is layer tunica vaginalis (internal spermatic fascia), and then under the layer there is tunica albuginea. Tunica albuginea lies in posterior part of the testis will form the testicular mediastinum. Connective tissue originating from the mediastimun will enter the inside of testis and divide testis into several lobules. Inside the lobule there are convoluted seminiferous tubule folds. Space around the folds of the seminiferous tubules is occupied by interstitial tissue. The seminiferous tubules form coils which at the end nortious will form the rete testis located in the mediastinum (Ravindranath et al., 2003).

Tunica vaginalis layer composed of several tissues, namely the visceral layer, parietal, and tunica dartos (Liguori et al., 2011, Phadmacanty et al., 2013). Both layers function as protective tissues and maintain internal temperature of the testis to remain stable.

Spermatogenesis is the process of forming sperm cells (male gametes) that occur in seminiferus tubular tissue. Process of spermatogenesis affected by thyroid hormones (Abadjieva et al., 2016). Spermatid and spermatocytes were initially formed at the age of 14-15 weeks (Morton, 1988). Sperm cells are released in the lumen area which will then lead to the epididymis for the process of maturing sperm. On the way to the epididymis, sperm will pass through rete testis and ductuli efferentes. Ductuli efferentes tissue are lie between testis and epididymis (Hussein, 2016). According to Adebayo et al (2010), epididymis is an epithelial tube consisting of five segments, namely: the initial segment, head, corpus, cauda, and vas deferens. Epididymis serve as a source of nutrients for sperm maturation (Pathak et al., 2014).

Rete testes are small tubules in the connective tissue which coated with a simple cuboidal epithelium that connects tubules recti and ductuli efferentes. Whereas ductuli efferentes (efferent ducts) have thinner walls than tubules recti (Khamas et al., 2014). Histology of Rete testes and Ductuli efferent are rarely studied. This article will describel histological study of rete testis and ductuli efferentes in rabbit.

\section{MATERIALS AND METHODS}

\section{Extraction of Male Reproductive Organs}

Two adult rabbits were used in this study. Rabbits were sacrificed by anesthesia using chloroform, then dissection was performed to remove testicular organs and their epididymis. The organs were fixed then in a bouin solution. The next process is dehydration of organs using multilevel alcohol solutions in a sequence, namely $30 \%, 40 \%, 50 \%, 60 \%, 70 \%, 80 \%, 90 \%, 96 \%$, absolute (each step took 1 hour). Then the organ is immersed in toluene solution overnight.

Organ then embed in paraffin. When paraffin had frozen, it ready to sliced using microtome. Sliced preparations were stained using Hematoxylin-Eosin dyes. Glass objects were soaked in xylol solution then alcohol solution from high concentration $(100 \%)$ to low concentration $(30 \%)$. Then immersed to dye solution 
(Hematoxylin-Eosin), then to the multilevel alcohol solution starting from low concentration (30\%) to high concentration $(100 \%)$. Finally put them into the xylol solution and mounted with glass objects.

\section{RESULTS AND DISCUSSION}

Anatomical observations of rabbit testis reveals several parts, namely the testis, ductuli efferentes, epididymis, and vas deferens (Figure 1). Tunica vaginalis serves to wrap the testicles, ductuli efferentes, epididymis, and vas deferens. In addition, the tunica vaginalis also serves as a protector and maintains the internal temperature of the testicles.

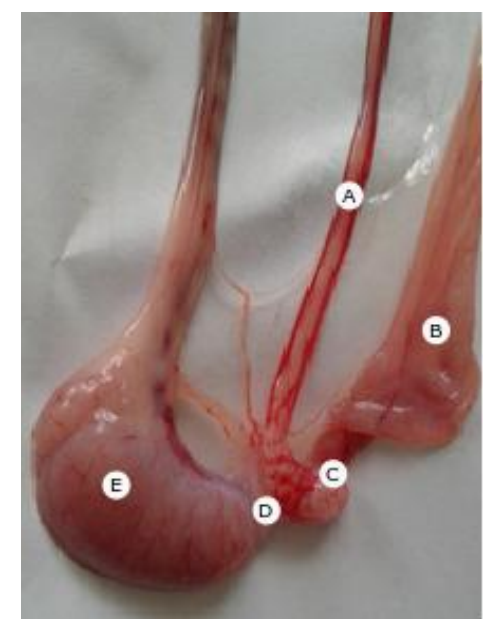

Figure 1. Rabbit testicles. A. vas deferens, B. Tunica vaginalis, C. epididymis, D. Ductuli efferentes, E. testis.

From the histological study data, it is obtained that rete restis structure and ductuli efferentes has a distinctive structure. Extension of the seminiferous tubule duct at the end will form rete testis. Rete testis tissue lie inside the testicular mediastinum. The rete testes ducts are straight elongated and have thin walls compared to the seminiferous tubule ducts (figure 2). In the reticular duct wall there are no stages of spermatozoa formation. Rete testis is only a duct for spermatozoa to pass to ductuli efferentes.

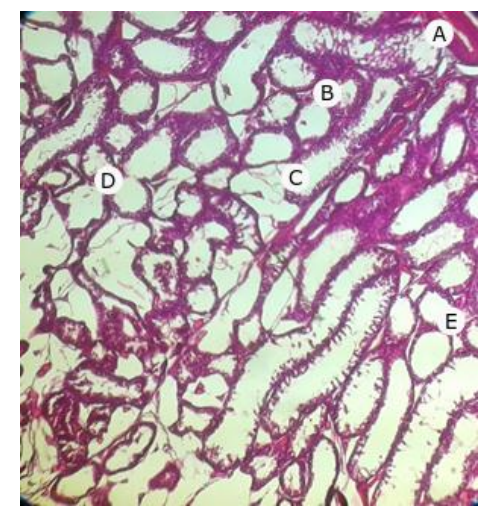

Figure 2. Cross section of rabbit testicles (Magnification 10x4) A. Blood vessel, B. Rete testis, C. Lumen, D. Seminiferous tubules, and E. Leydig cell.
Ductuli efferentes are laid between the rete testis and epididymis (figure 3). Microanatomical observations show that ductuli efferentes have thin walls and their ducts lead to the epididymis. Ductuli efferentes serve as a ducts for spermatozoa to the epididymis and then passing out through the vas deferens ducts. In the epididymis the spermatozoa accumulate and mature into sperm. Mature sperm then go to the vas deferens part.

A

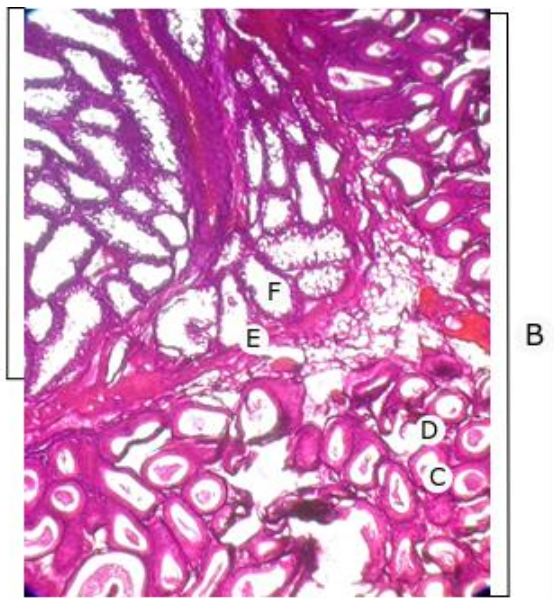

Figure 3. Longitudinal slices of the testicles and epididymis (Magnification 10x4). A. Collection of seminiferous tubules, B. Epididymis, C. Spermatozoa, D. Basement membrane. E. Ductuli efferentes, F. Lumen Ductuli efferentes.

\section{CONCLUSIONS}

From the macroanatomical and microanatomy studies it can be concluded that the transport of sperm to the vas deferens canal is through several ducts. The initial transit starts from the semeniferus tubules as a place for spermatozoa formation, then leads to the rete testis part, then to the ductuli efferent, then to epididymis, and finally to vas deferens and urethra.

\section{REFERENCES}

Abadjieva, D et al. 2016. Testicular Morphometry and Histology of Rabbit Bucks Supplemented with Iodine in Drinking Water. Asian Journal of Animal and Veterinary Advances. Vol 11 (8): 491-497.

Adebayo, A. O and S.A. Olurode, S.A. 2010. The morphology and morphometry of the epididymis in the greater cane rat (Thryonomys swinderianus Temmincks). Folia Morphol. Vol. 69, No. 4, pp. 246-252.

Ahmed, Y. A. Histological and Histomorphometric Changes of the Rabbit Testis During Postnatal Development. Research Journal of Veterinary Sciences. Vol. 5 (2), pp: 42-50.

Caldeira et al. 2010. Morphometry of testis and seminiferous tubules of the adult crab-eating fox (Cerdocyon thous, Linnaeus, 1766). Rev. Ceres, Viçosa, vol. 57(5), p: 569-575.

Hussein, S. 2016. Histological, histochemical and ultrastructural characterizations of the epididymal region of the turkey (Meleagrisgallopavo). Research Journal of Pharmaceutical, Biological and Chemical Sciences. Vol. 7 (3): 1359-1369.

Khamas et al. 2014. Histological Description of the Testis, Epididymis and Ductus Deferens of the Northern Great Grey 
Kangaroo (Macropus giganteus giganteus). Journal Cytology \& Histology. Vol. 5 (6): 1-6.

Kiernan, J. A. 1990. Histological \& Histochemical Methods: Theory and Practice. Second edition. New York: Pergamon Press.

Lakabi et al. 2016. Histological and Histomorphometric Changes in Testis during Postnatal Development of Rabbit from Local Population in Algeria. Journal of Cytology \& Histology. Vol 7 (2), pp: $1-10$

Lee G. Luna, H. T. 1968. Manual of Histologic Staining Methods of The Armed Forces Institute of Pathology. Third Edition. New York: McGraw-Hill Book Company.

Liguori, et al. 2011. Anatomy of the Scrotum. Springer-Verlag Berlin Heidelberg. P: 1-8.

Mahmoud Mehanna et al. 2016. Morphology of the testes and epididymal ducts in the pampas cat Leopardus colocolo (Molina, 1782) ${ }^{1}$. Pesq. Vet. Bras. 36(10):1014-1020.

Morton, D. 1988. The Use of Rabbits in Male Reproductive Toxicology. Environmental Health Perspectives. Vol. 77, pp: 59.

Ogbuewu et al. 2009. Semen quality characteristics, reaction time, testis weight and seminiferous tubule diameter of buck rabbits fed neem (Azadirachta indica A. Juss) leaf meal based diets. Iranian Journal of Reproductive Medicine. Vol.7. No.1. pp: 2328

Phadmacanty et al. 2013. Organ Reproduksi Jantan Sulawesi Giant Rat (Paruromys dominator). Jurnal Sain Veteriner. 31 (1): 100109.

Pathak, et al. 2014. Postnatal Developmental Anatomy of Testes and Epididymis of Gaddi Goats. Int. J. Morphol., 32(4):1391-1398.

Ravindranath et al, 2003. Introduction to Mammalian Reproduction. Springer, Boston, MA. Georgetown University School of Medicine, Washington, DC, USA.

Razi, M. et al. 2010. Histological and anatomical study of the White Rooster of testis, epididymis and ductus deferens. International Journal of Veterinary Research. Vol. 4 (4) pp: 229-236.

Suntoro, S.H. 1983. Metode Pewarnaan (Histologi dan Histokimia). Jakarta: Bhratara Karya Aksara.

Zamora, E. J. L et al. 2014. Histoloical Description of The Rabbit (Oryctolagus cuniculus) Epididymis and Testicles. Universdad Autonoma del Estado de Mexico. pp: 205-219. 
THIIS PAGE INTENTIONALLY LEFT BLANK 